\title{
Promoting Students' Reading Proficiency Through Reciprocal Technique
}

\author{
Farid Noor Romadlon \\ Universitas Muria Kudus \\ farid.noor@umk.ac.id
}

\begin{abstract}
Teaching English in High School level (Junior High School and Senior High School) is more exposed in reading and writing skills for the target of the final examination (UN). Consequently, students need to sharpen their reading and writing ability. It also must be done by students in a non-formal Senior High School known as KejarPaket $C$ without any exception. Improving reading skill can bedone through doing more reading activities in various types of text. This activity will add students' vocabularies and their knowledge about more topics of the texts. Besides, the way teachers deliver the material deals with techniques, methods, or strategies also contributes to students' progress of reading skill. Seeing the background of students in KejarPaket $C$ who have various backgrounds and most are from low economic level or less motivated students for studying, teachers should concern more in exposing the material through the appropriate and effective technique. Carter (2001) brings an idea about a technique which teacher and students are taking place in dialogue, and it resulted in students learning how to construct meaning when they are placed in must-read situations (tests or assignments). It was experimental research which was conducted to find the difference in students' reading proficiency taught by using a technique called Reciprocal. The study found that the technique contributed significantly to improving students' reading proficiency after they were taught by using Reciprocal.
\end{abstract}

ARTICLE HISTORY

Received 19 April 2017

Accepted21 August 2017

\section{KEYWORDS}

Reading proficiency; KejarPaket C; Reciprocal technique

\section{Introduction}

It has been known that final examination (UN) is the target of teaching English at schools in Indonesia. Mastering all skills of English is necessary, but since the teaching and learning process is more emphasized to reading and writing skills for reaching the passing grade indicator or StandarKompetensiLulusan (SKL) in final examination (UN), students need to practice and sharpen especially their reading skill. To be able to have a good reading skill, students must do more reading activities both for free reading and thematic reading activity.

Doing the reading activities in teaching reading cannot be relied on to be the only practice in improving students' reading skill because since the teaching reading at schools is genre-based teach-ing, teachers then rely on the textbook to drill the students which results in an annoying situation. The teaching process is not delivered 
in variant teaching techniques, which these contribute more in motivating students to be actively participating in reading activity both in and outside of class.

Textbook-based teaching, a monotone teaching activity, less exposure in reading activity are the description of teaching reading in KejarPaket $C$. It happens because of very complex factors such as teachers regard that KejarPaket $C$ is a nonformal school administered by the government and so has lower level of significance than Senior High Schools, students have less motivation to understand or even study the materials given because their willing is only getting the equal-standardized certificate as Senior High Schools, limited facilities to support the teaching and learning process e.g. books, learning media, rooms, etc. This condition results in students who still have less ability in reading skill. They are still difficult in understanding the text, sentences in the text, and vocabularies from the text. It makes students challenging to understand the materials given, and in the end, most of them do not get a good score or less than the standard score. What has been experienced by students worsened by the way teachers deliver the material. In the teaching process, teachers only teach about the text through lecturing and highlighting it. Teachers read the text and ask students to identify new vocabularies thenteachers give the meaning and the last asking students to answer the text questions for about ten to fifteen minutes. Unfortunately, during the exercise teachers use the time for sitting, not controlling students' work. This runs continuously, so students are getting bored to study and do class action because the action is the same from meeting to meeting, the texts discussed are not variant. They are just taken from the textbook. Teachers do not have any other references or ask students to find another text as the enrichment.

Teaching reading must be creative and update. Here, teachers must put the doer or the actor to the students, not they. Giving the more variant texts from current issue should be done by the teachers besides discussing the text model taken from the textbook, so students will have more opulent references as their background and enrichment in understanding different texts. Conducting different technique in teaching reading is also necessary to expose students' motivation in doing a reading activity and to upgrade their comprehension in reading text through different techniques. Students will be motivated to do a reading activity, improve their vocabularies, to get familiar in mapping the information from the text when teachers provide variant texts and techniques in teaching.

\section{Reading Comprehension}

Reading is one of four skills that should be mastered by the students in learning English either as a second language or a foreign language. Reading is not only an active and communicative process but also an interactive process that goes on between the reader and the text, resulting in comprehension. The process involves 
the reader, the text, and the interaction between the reader and the text. The text presents letters, words, sentences, and paragraphs that encode meaning. Meanwhile, the reader uses knowledge, skills, and strategies in order to construct the meaning of the text.

Moreover, reading cannot be separated from comprehension because the result of the reading activity is to comprehend what has been read. Reading without comprehending what has been read is pointless. According to Grabeet. et al. (2001: 33), "Reading is the ability to draw meaning from the printed page and interpret this information appropriately." In line with Grabe, Paul(1993: 461) as cited in Surjosuseno (2010: 4) defines reading as an active intellectually en-gaged processing which the reader participates in an inner dialogue with the writer. It means that when the reader reads the text, he not only reads and understands it, but also thinks and participates in the text by relating the author's ideas or information to his own experience or problem. In other words, reading is the interaction between the text (the author) and the reader by combining information from the text and the reader's prior knowledge. In the educational field, reading holds a vital role in helping students to learn more information from another.

Besides, Grabeet. et al. (2002: 17) state, "Reading for general comprehension is, in its most obvious sense, the ability to understand information in a text and interpret it appropriately." It is supported by Pang et al. (2003: 6) who argue, "Comprehension is the process of making sense of words, sentences, and connected text."

It can be summarized that reading comprehension is the ability to draw meaning by the process of making sense of words, sentences, and connected text. In simple, reading comprehension is the process in which case the reader understands the text that has been read.

On the one hand, readers process texts in two ways, either Bottom-up or Topdown (Harmer, 2001: 201). He states that in top-down processing, the reader or listener gets a general view of the reading passage by, in some way, absorbing the overall picture. Besides, Goodman (as cited in Brown, 2001: 299) states, "Top-down is processing in which we draw on our intelligence and experience to understand a text. Thus, in top-down processing the readers construct meaning through clues in the text and the reader's good schema knowledge, they do not read word for word but quickly and efficiently. Meanwhile, Harmer (2001: 201) also states that in bottom-up processing, on the other hand, the reader focuses on individual words or phrases, and achieves understanding by stringing these specific elements together to build up a whole.

Furthermore, Goodman states that in bottom-up processing readers must first recognize a multiplicity of linguistic signals (letters, morphemes,syllables, words, phrases, grammatical cues, and discourse markers) and use their exact data processing mechanism to impose some order on the linguistic signals. It means that 
in bottom-up processing the reader builds up meaning by reading a word for word, letter for letter. A combination of top-down and bottom-up processing; called as interactive reading; is supporting the success in teaching because both of them are important. Thus, a top-down approach is used to predict probable meaning, and bottom-up approach is used to check it (Nuttal as cited in Brown, 2001: 299).

\section{Level of Comprehension}

As teachers of English as a foreign language, the teachershould be aware that the primary objective of reading is comprehension or being able to find meaning in what is read. However,some teachers often designed the comprehension questions only to check the students' ability in recalling ideas and information directly stated in the given text.

Burn et al. (1984:177-178) as cited by Novthami (2011) categorize reading comprehension into four categories namely, literal reading, interpretive reading, critical reading, and creative reading.

1. Literal Reading

Reading for literal comprehension involves acquiring information that is directly stated in a selection. The answer to critical question demands the students from memory what the book says. Literal comprehension is the lowest level type understanding.

\section{Interpretive Reading}

The imperative involving reading between the lines or making is not directly stated in the text but suggested or implied. Interpretive levels of reading comprehension go beyond literal comprehension.

\section{Critical Reading}

Critical reading means reading to assess or review ideas. This also involves intense concentration. Burn views that the essential reading is an evaluation of the ideas in the materials with known standard and conclusion about accuracy appropriate-ness. In the critical reading, a reader must be collected, analyze and synthesize the information.

\section{Creative Reading}

The creative reading involves going beyond the material presented by the creative author and requires the students to think as they read and to use their imagination. In creative reading, the reader tries to come up with a new or alternative solution to those presented by the author.

It can be stated that the purpose of reading is to connect ideas on the page to what readers already know. A person may read for enjoyment, or to enhance knowledge of the language being read.

In conclusion, the purposes of reading comprehension are to get the idea of the text, to gain the information based on the reader's needs and purposes, read for 
enjoyment, and read to enhance knowledge.

\section{Teaching Reading}

The aim of teaching English is to improve the students' communication ability in English which consist of four skills; they are listening, speaking, reading, and writing. Brown (2000: 7) states, "Teaching is guiding and facilitating learning, enabling the learner to learn, setting the conditions for learning." As stated previously, reading is the ability to draw meaning from the printed page and interpret this information appropriately (Grabe et al., 2001: 33). In conclusion, teaching reading is guiding, facilitating, and setting the condition for learning that enabling the students to learn in a comfortable environment, so that the students can understand the text easily.

Besides, Harmer (2001: 70) states that there are six principles behind the teaching of reading. They are as follows:

1. Reading is not a passive skill

Reading is an incredibly ongoing occupation. To do it successfully, we have to understand what the words mean, see the words mean, see the pictures the words are painting, understands the arguments, and work out if we agree with them. If we do notdo these things, then we only scratch the surface of the text, and we quickly forget it.

2. Students need to be engaged with what they are reading

As with everything else in a lesson, students who are not engaged with the reading text-not actively interested in what they are doing are less likely to benefit from it. When they are rarely fired up by the topic or the task, they get much more from what in front of them.

3. A student should be engaged to respond to the content of reading a text, not just to the languages.

It is essential to study readings for the way they use language, the number of the paragraphs they contain and how many times they use relative clauses. However, the meaning, the message of the text, is just as important and we must give students a chance to respond to that message in some way. It is especially important that they should be allowed to express their feelings about the topic-thus provoking personal engagement with it and the language.

4. Prediction is a significant factor in reading

When we read a text in our language, we frequently have a good idea of the content before we read. Book cover gives us a hint of what is the book, photographs and headlines hint at what articles are about and report before we read a single word.

The moment we get this hint - the book cover, the headline, the word 
processed page - our brains starts predicting what we are going to read. Expectations are set up, and the active process of reading is ready to begin. The teacher should give students 'hints' so that they can predict what's coming too. It will make them better and more engaged readers.

\section{Match the Task to the Topic}

Once a decision has been taken about what reading text the students are going to read, teachers need to choose good reading tasks - the right kind of questions, engaging and useful puzzles.

6. Good teachers exploit reading text to the full

Any reading text is full of sentences, words, ideas, descriptions, etc. it does not make sense to get the students to read it and drop it to move on to something else. Good teachers integrate the reading text into interesting class sequences, using the topic for discussion and further tasks, using the language for study and later activation.

\section{Reciprocal as Technique in Teaching Reading}

The teacher usually has some preparations before the teaching and learning process done, so the teaching and learning activity can run well. It can be done by determining the method; the teacher will use the technique, and strategy. Meanwhile, there are many kinds of methods, techniques, and the teacher can use strategies. Reciprocal teaching technique is one of the techniques that much able to assist the teaching process in reading class. For the further understanding about Reciprocal teaching technique, it will be explained deeper about technique, then the more indepth explanation about Reciprocal Teaching as a technique in teaching reading, and the steps in teaching reading by using reciprocal teaching.

The technique of teaching that is used by the teacher is a significant thing in the teaching-learning process. It can give a significant impact on whether for the students or the teacher. If the teacher does not use the appropriate technique in teaching the students, the teaching and learning process will never run well, and the result may be not too satisfied. The teacher has to be able as bright as possible in choosing the appropriate strategy based on the material that the students' need and also the students' characteristic. Almost the entire students get difficulties in understanding the text. Therefore, improving the teachers' teaching technique is one solution to improve the students' reading comprehension.

Reciprocal is an instructional technique in which students and teacher take turns leading a dialogue about strategies for how to study some materials (Padma, 2008). Moreover, reciprocal teaching is an excellent technique which aids the teaching process. It consists of therapeutic strategies, aimed at developing and enhancing reading comprehension. Reciprocal teaching technique may be used as 
oneof several teaching techniques within a balanced reading program. Moreover, reciprocal teaching technique is a great technique to get students actively involved in their reading, to monitor themselves, and significantly improve their reading comprehension. It is supported by a psychologist that students will get the benefit when the teacher actively involves them in conversation, gives some questions, and emphasizes on interactive language rather than directive language (Santrock, 2009: 74). During reciprocal teaching technique applied, the teacher and students take turns assuming the role of the teacher in leading the dialog, which leads to an exciting group learning experience (Palincsaret. al, 1984: 124). Moreover, the role of the teacher here is as the facilitator and controller.

Strategies can be used as tools for active, self-directed involvement in developing the students' competence (Nuswantara in Cahyono, 2010). The strategy results in improved proficiency and greater confidence. Thus, there are four basic strategies in reciprocal teaching technique that can help the students to enhance their understanding and enable them to grasp information from the given text, if the strategies applied while reading process.

\section{Methodology}

This study is an experimental one which is conducted to improve the students of KejarPaket $C$ reading ability. The variables which were described the students' reading ability as the dependent variable and reciprocal teaching technique as the independent variable. In collecting the data, an instrument was used to measure the reading ability of the students. The instruments were the observation sheet and reading test consists of 25 items of questions and five texts. It is in the form of multiple choices.

\section{Teaching Reading by Using Reciprocal Technique}

The pre-test was administered to get the scores in recount text topic as the preliminary data. These are aimed to know whether is there any problem faced by the students in studying English. In the early condition, the result of the test in reading comprehension of recount text indicated that most of them got the score less than thetarget score. Considering the facts explained above, the treatments which consist of different activities and a new technique (Reciprocal technique) were designed to find the difference between their reading comprehension before and after the treatments. It was assumed that teaching reading using Reciprocal teaching technique would improve the students' reading comprehension and changed their as-sumptions toward English lesson, especially in reading comprehension. The instruments were also prepared to complete the data and strengthen this study finding such as test and observation sheets. 
The reciprocal technique was combined with Three Phase Technique which consisted of three activities. They are pre-activity, whilst-activity, post-activity. The steps took 60 minutes in one meeting. The procedures were explained to students before they directly did Reciprocal technique activities. The teacher (researcher) showed a picture and asked them to predict what the title of the text was. Then, a title of the text was given and the students were guided whether they wanted to confirm or reject their prediction. From the title they got, students were asked to predict what the text would talk about; they could use their prior knowledge to predict the text content. After that, the teacher showed the first paragraph and asked the students to read it silently. The teacher and the students discussed the content of the first paragraph, included the generic structure. It was repeated until the end of the paragraph. The next strategy was clarifying. The students were guided to identify what aspects in the text that they needed to clarify. After that, in the questioning phase, the teacher guided the students to generate questions about the passage that they do not fully understand yet. Some questions were given to check the students' understanding. Teacher-guided the students to summarize the text orally as the last strategy in these activities.

The next stage was dividing the students into some groups consisted of four people for each group, and one group consisted of 5 people. The teacher determined one student of each group who has higher reading ability than other members as 'teacher' student for assisting the group in doing the activities. Then, the teacher concluded the material, gave them a chance to ask questions, and closed the teaching-learning activities.

The treatments showed that the implementation of reciprocal teaching technique brought some positive results for the students. The students were active in the teaching and learning process. They were not shy in delivering their opinion and their questions. It could be seen on the notes of the observational sheet that the students actively answered and responded to the teacher's questions. They were also active in delivering their opinion to predict the text, to ask about what aspect that they needed to clarify, to generate a question, and to deliver their idea in summarizing the text. The atmosphere of the class made the students enjoyed the teaching and learning activities. They did reading activities not as an individual activity again or just read aloud the text, but they also actively got involved in a dialogue with their friends in order to comprehend the text. Moreover, they had to learn communities to solve their problem in understanding the material. It encouraged the students to learn reading.

It was supported by the obtained data from the observational sheet and the students' achievement test in reading comprehension. The data from the observational sheet showed that $84.62 \%$ of the teacher's and the students' activities ran well. Referring to the result of the observational sheet in the first treatment or before taught by using Reciprocal technique, it was significantly improved. 
Meanwhile, from the result of the students' achievement test, the result was also improved. The students' average score was $87.6(87.6 \%)$ which could be categorized as excellent. Moreover, all of the students (100\%) consisted of 13 students could reach the score target. Two students got a perfect score that was 100 . The following table is the recapitulation of the teacher's and the students' activities in the first treatment and the last (fourth) treatment:

\begin{tabular}{lllll}
\hline & 1st meeting & \multicolumn{2}{c}{ 4th meeting } \\
\hline & Teacher's & Students' & Teacher's & Students' \\
\hline & Activities & Activities & Activities & Activities \\
\hline Average & & & & \\
\hline & $83.3 \%$ & $77.8 \%$ & $84.62 \%$ & $84.62 \%$ \\
\cline { 3 - 5 } Category & Good & & Good & \\
\hline
\end{tabular}

Table 4.1Recapitulation of Average Scores of the Teacher's and the Students' Activities in Teaching Reading Comprehension of Re-count Text by Using Reciprocal Teaching Technique

From the data listed in Table 4.1, the bar diagram can be seen in the following figure:

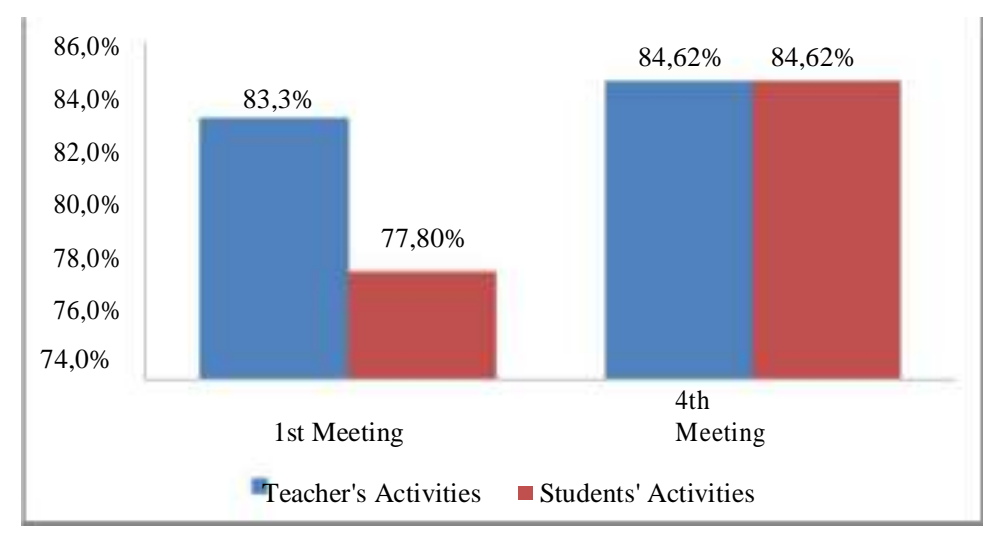

Figure 4.1The Bar Diagram of Percentage Scores of Teacher's and Students' Activities in Teaching Reading Comprehension of Re-count Text by Using Reciprocal Teaching Technique of KejarPaket C Students, Cendikia Kudus

Based on the table, the improvement of the students' reading comprehension in 
recount text taught by using Reciprocal teaching technique in first treatment was good. Meanwhile, the students' achievement in the last treatment was excellent. The students' average score of the students' pre-test was $69(69 \%)$ which $7(67.7 \%)$ students could not reach the score target. The result showed a significant difference. The students' average scores in first treatment were 78.3 (78.3\%); 5 (17.65\%) students could not reach the target. It was better improved in last treatment to be 87.6 $(87.6 \%)$ where all of the students $(100 \%)$ reached the target.

\section{Conclusion}

Based on the result it can be concluded that teaching reading comprehension by using Reciprocal teaching technique was sufficient to contribute a significant difference result in students' achievement dealing with their reading comprehension proficiency. 


\section{References}

Arikunto, Suharsimi. (2006). Prosedur Penelitian Suatu Pendekatan Prak tik. Jakarta: RineksaCipta.

Brown, H. Douglas. (2001). Teaching by Principles: An Interactive Ap-

Approach to Language Pedagogy. New York: Pearson Education.

Cahyono, BambangYudi. (2010). The Teaching of English LanguageSkills and English Language Component. Malang: State Universityof Malang Press

Carter, C., and Fekete, D. (2001).Reciprocal Teaching: the application ofA Reading Improvement Strategy on Urban Students in Highland Park, Michigan, 199395 (Innodata Monographs - 8). Geneva, Switzerland: International Bureau of Education.

Choo, Tan OoiLeng.,Eng, Tan Kok., and Ahmad, Norlida. (2011).

Effects of Reciprocal Teaching Strategies on Reading Comprehension.

The Reading Matrix, Volume 11, Number 2, 140-149.

Fraenkel, Jack. R., and Norman .E. Wallen. (2007). How to Design andEvaluate Research in Education. New York: McGraw-Hill Companies.

Grabe, William., and Stoller, Fredricka L. (2002). Teaching and Researching Reading. London: Pearson Education.

Harmer, Jerremy. (2003). The Practice of English Language Teaching.

England: Longman 